УДК 341.11

DOI https://doi.org/10.32837/apdp.v0i87.2818

I. В. Хостюк

\title{
МІЖНАРОДНО-ПРАВОВА ПРОБЛЕМАТИКА СКАСУВАННЯ ПРАВА ВЕТО ПОСТІЙНИХ ЧЛЕНІВ РАДИ БЕЗПЕКИ ОРГАНІЗАЦІЇ ОБ'СДНАНИХ НАЦІЙ
}

Постановка проблеми дослідження. Право вето постійних членів Ради Безпеки Організації Об'єднаних Націй (далі - ООН) є одним із найважливіших аспектів їхнього міжнародно-правового статусу. Воно є не просто особливою юридичною конструкцією в контексті принципу суверенної рівності держав, а й інструментом, який було надано міжнародною спільнотою окремим державам із метою гарантування міжнародного миру та безпеки. Проте дуже часто дискутується питання щодо реформування права вето як такого, яке в поточному вигляді перешкоджає ефективній діяльності Ради Безпеки й ООН загалом.

Мета цього дослідження - узагальнення пропозицій щодо реформування права вето постійних членів Ради Безпеки ООН у доктрині права міжнародних організацій.

Стан дослідження проблеми. В українській міжнародно-правовій доктрині дослідження, присвячені реформуванню права вето постійних членів Ради Безпеки ООН, здійснювали Р. Губань, Л. Дорош, С. Охремчук, І. Черінько й інші. У закордонній правовій науці варто виділити праці Ф. Вілкокса, П. Маланчука, А. Петерс таінших. Протекомплексного дослідження зазначеноїпроблеми зурахуваннямпропозицій щодо цього у вітчизняній науці міжнародного права нині не проводилося.

Виклад основного матеріалу. Майже протягом усієї своєї сімдесятип'ятирічної історії $\mathrm{OOH}$ постійно зазнавала критики через свою діяльність. Організацію часто називали неефективною, зокрема через неспроможність забезпечити міжнародний правопорядок та верховенство міжнародного права в міжнародних відносинах. Ця критика супроводжувалася також пропозиціями щодо можливого реформування внутрішньоорганізаційного механізму ООН, зокрема міжнародно-правового статусу постійних членів Ради Безпеки (далі - РБ) ООН.

$\mathrm{y}$ цьому контексті дискусія зазвичай ведеться у двох основних напрямах: по-перше, збільшення кількості постійних членів Ради; по-друге, скасування їхнього права вето. Представники доктрини міжнародного права підкреслюють важливість вирішення саме цього питання в контексті реформування РБ ООН. Так, Р. Гейгер зазначає, що «справжньою проблемою реформування Радбезу $€$ не стільки постійне членство, як їхнє право вето» $[1$, с. 759$]$.

Навіть більше, окремі дослідники розглядають право вето як ключову проблему того, що РБ ООН на різних етапах зарекомендувала себе як неефективна міжнародна інституція. На думку А. Петерс, «після початкового періоду, протягом якого РБ ООН функціонувала належним чином, та з інтенсифікацією конфлікту між Сходом та Заходом на початку 1950-х рр., Радбез став бездіяльним через часте застосування права вето її постійними членами» [1, с. 764]. 
Тому цілком логічно, що висловлювалися пропозиції стосовно вдосконалення цього інструменту: як щодо повного скасування права вето постійних членів Ради, так і щодо внесення змін до цього механізму, зокрема через його обмеження. На думку Р. Губаня, «основними причинами, які зумовлювали необхідність проведення реформи Ради Безпеки ООН, стали питання щодо правила одностайності великих держав та стосовно надання права вето постійним членам Ради Безпеки $\mathrm{OOH}$ » $[2$, с. 70$]$.

Проте якщо ми говоримо про проблематику скасування чи обмеження права вето постійних членів РБ ООН, варто розуміти, що вони є частиною загального дискурсу стосовно реформування Ради. Тому доцільно розглядати його в контексті і, у рамках цього дослідження, висвітлити питання реформування РБ ООН загалом. У цьому контексті необхідно зазначити, що предметні дискусії в доктрині міжнародного права щодо цього тривають уже давно. Як слушно зазначає Р. Губань, «проблема реформи Ради Безпеки ООН виникає водночас зі створенням Організації Об’єднаних Націй» [2, с. 70].

Варто особливо наголосити, що доцільність та потреба в реформуванні РБ ООН визнається і на офіційному рівні. Зокрема, у доповіді Спеціальної комісії міжнародних експертів високого рівня 2004 р. мета такого реформування РБ ООН сформульована як «збільшення ефективності та довіри до Ради Безпеки, а головне - посилення її спроможності та готовності діяти в умовах загроз» [3]. У цій же доповіді було визначено основні критерії, яким має відповідати таке реформування, а саме:

1. Підвищення рівня залученості до процесу ухвалення рішень у РБ ООН держав, які роблять найбільший фінансовий, військовий та дипломатичний внесок у діяльність Організації.

2. Збільшення репрезентативності процесу ухвалення рішень у РБ $\mathrm{OOH}$ через запровадження більш широкого членства в Раді, зокрема держав, що розвиваються.

3. Недопущення зниження ефективності діяльності РБ ООН.

4. Посилення демократичної природи РБ ООН та її підзвітності [3].

Робоча група наголошувала, що цим критеріям повинно відповідати і потенційне розширення членського складу РБ ООН, про що йтиметься нижче [3].

Питання міжнародно-правового статусу постійних членів Ради в частині можливості застосування права вето перебувають у центрі відповідних дискусій. Ми зупинимося на ключових пропозиціях щодо зміни (скасування або обмеження) права вето постійних членів РБ ООН.

Варто наголосити, що у практиці міжнародно-правових відносин питання потенційного скасування права вето постійних членів РБ ООН обговорювалося практично від самого початку створення організації. Американський учений Ф.О. Вілкокс відзначав, що ще під час конференції в Сан-Франциско «багато делегатів заявляли, що вони не заперечували б проти права вето так активно, якби вони отримали певні гарантії, що процес внесення змін до Статуту ООН може бути лібералізовано і з'явиться можливість для переосмислення Організації в майбутньому» [4, с. 950]. Хоча тут право вето протиставлялося внесенню змін до Статуту ООН, можна дійти висновку, що держави, які не були наділені правом вето, прагнули забезпечити можливість скасування цього права вето в довгостроковій перспективі. 
Проте «малі» держави, попри те, що «довго і гучно дискутували стосовно скасування права вето щодо поправок до Статуту запропонованих всезагальною конференцією з перегляду» [4, с. 951], змогли добитися лише часткового його обмеження, зафіксованого в п. 2 ст. 109 Статуту (неможливість блокування скликання та роботи конференції щодо перегляду Статуту $\mathrm{OOH}$ постійними членами через застосування права вето) [5]. Проте цей компроміс, досягнутий на самому початку створення й існування $\mathrm{OOH}$, не знімав питання, відтоді йде активне обговорення доцільності повного скасування чи подальшого обмеження права вето постійних членів РБ ООН як у науці, так і у практиці міжнародного права.

Водночас навіть ті, хто в 1945 р. загалом прихильно ставилися до ідеї закріплення права вето постійних членів РБ ООН, не розглядали це як вічний елемент їхнього міжнародно-правового статусу і навіть вказували на тимчасовий, ситуативний характер цього положення. Той же Ф.О. Вілкокс стверджував: «Якщо ж тоді «великодержавна одноголосність» сьогодні є sine qua non для Об'єднаних Націй, ми повинні прийняти їі як тимчасову фазу розвитку світової організації та докласти всіх зусиль, щоб вона запрацювала», а також підкреслював, що із часом ООН буде спроможна «впровадити більше методів та технік справді демократичної інституції» [4, с. 954]. Проте після сімдесяти п'яти років функціонування РБ ООН можна констатувати, що сприйняття тимчасового характеру права вето постійних членів не пройшло перевірку часом і нині не може розглядатися як реалістичне.

Також у контексті міжнародно-правових дискусій щодо цього, які велися в перші роки існування ООН, необхідно згадати Консультативний висновок Міжнародного Суду ООН щодо компетенції Генеральної Асамблеї в питанні прийому держав до складу ООН від 3 березня 1950 р. Хоч у ньому Суд і підтримав необхідність урахування права вето постійних членів Ради Безпеки ООН під час ухвалення рекомендації про прийом нових членів $\mathrm{OOH}$, двоє суддів - чилієць А. Альварес та бразилець Ф. Асеведо висловили окремі застереження саме в частині застосування права вето в цьому локальному питанні.

Якщо Ф. Асеведо виходив із позицій, що право вето не може застосовуватися до прийому нових членів, оскільки це питання є процедурним, то А. Альварес розглядав можливість процедурного обмеження застосування права вето під час розгляду такого роду питань. Зокрема, він пропонував наділити ГА ООН правом надавати оцінку допустимості застосування постійними членами РБ ООН права вето під час ухвалення рекомендації Ради про прийом нових членів Організації. На його переконання, ГА ООН повинна була давати оцінку того, наскільки застосування права вето відповідало цілям Статуту ООН і чи не було воно зловживанням цим правом із боку постійних членів РБ ООН. Якщо ж було б установлено, що мало місце зловживання, то Асамблея отримувала б право прийняти нового члена і без рекомендації РБ ООН [6, с. 20-21].

Дискусії щодо обмеження чи скасування права вето постійних членів РБ ООН активно ведуться і на сучасному етапі, зокрема на доктринальному рівні. Наприклад, І. Черінько вважає, що «право вето в Раді Безпеки ООН не відповідає реаліям сучасного світу» [7, с. 139]. Л. Дорош і С. Охремчук зазначають, що "саме право вето є основною перешкодою у виконанні Радою її основних функцій - збереження миру та безпеки, і вимагає першочергової уваги міжнародної спільноти» [8, с. 22]. 
Своєю чергою, П. Маланчук зазначає, що процедура голосування у РБ ООН піддається жорсткій критиці, оскільки «не відбиває змін, що сталися в міжнародній системі від 1945 р. [9, с. 512]. Схожу позицію було підтримано в доповіді Спеціальної комісії міжнародних експертів 2004 р., де зазначено, що «інститут вето має анахронічний характер, який непридатний для інституції в дедалі більш демократичному часі» [3].

Представники міжнародно-правової доктрини також прямо вказують на те, що застосування права вето або ж збереження алгоритму його функціонування в чинній формі може спричиняти ризики для діяльності ООН загалом. Наприклад, Р. Гейгер наголошує, що «ситуація (із застосуванням права вето постійними членами РБ $\mathrm{OOH}$ - I. Х.) може стати згубною для авторитету Радбезу, особливо коли постійні члени застосуванням права вето не дають Раді можливості виконувати свої функції, передбачені гл. VII Статуту ОOH» [1, с. 760]. На думку іншого юриста-міжнародника К. ван Кестерен, «людство повинне створити іншу модель роботи планети; потрібні нові форми глобального управління» [10, с. 261].

Навіть більше, експерти припускають, що наслідком невдоволення міжнародною спільнотою такою патовою ситуацією та неефективністю $\mathrm{OOH}$ може бути створення альтернативної міжнародної організації. Так, Р. Гейгер уважає, що «більшість «звичайних» держав - членів ООН можуть мати спокусу створити нові міжнародні об'єднання, які у своїх основоположних засадах не будуть приписувати аристократичні привілеї одній чи більше «високопоставленим державам» $[1$, с. 760$]$.

Як шляхи вирішення ситуації, що склалася, у науковій доктрині було сформульовано конкретні пропозиції щодо можливості скасування чи реформування права вето постійних членів РБ ООН. Зокрема, Л. Дорош та С. Охремчук проаналізували ці пропозиції та виділили основні ідеї щодо зміни порядку ухвалення рішень РБ ООН та застосування права вето, як-от:

1. Ухвалення рішень у РБ ООН консенсусом усіх членів.

2. Добровільна відмова постійних членів РБ ООН від використання свого права вето у випадках учинення міжнародних злочинів (геноцид, злочини проти людства та масштабні військові злочини).

3. Дозвіл на застосування права вето в разі, якщо проти рішення водночас проголосували два або більше постійних членів РБ ООН.

4. Дозвіл застосування права вето виключно щодо питань, передбачених гл. VII Статуту ООН ( «Дії щодо загрози миру, порушень миру й актів агресії).

5. Уведення можливості подолання права вето двома третинами голосів складу РБ ООН.

6. Ліквідація права вето загалом [8, с. 22-23].

Окрім наукового дискурсу щодо права вето в діяльності РБ ООН, на сучасному етапі ведеться і формальна дискусія в рамках офіційних механізмів ООН. Так, Робоча група з питань справедливого представництва та збільшення членства в Раді Безпеки та інших питань, що стосуються Ради Безпеки, яка була створена в 1993 p. i, серед іншого, розглядала питання про «Ухвалення рішень у Раді Безпеки, включно з питанням права вето» [11]. 
У звіті Робочої групи, хай і побічно, але вказувалося на надзвичайно дражливий і політичний характер права вето постійних членів РБ ООН і необхідність обережно підходити до винесення його на розгляд. Зокрема, у частині можливості надання права вето новим постійним членам РБ ООН зазначалося, що «поширення права вето на нових постійних членів має розглядатися наприкінці досягнення угоди щодо пакета реформ» [11], вочевидь, щоб це питання не заблокувало розгляд реформ у принципі.

У звіті Робочої групи також було запропоновано кілька підходів до застосування права вето після завершення процесу реформування Ради, а саме:

- нові постійні члени РБ ООН мають отримати ті самі повноваження та привілеї, що і чинні постійні члени;

- наділення нових постійних членів РБ ООН правом вето з одночасним установленням обмежень для застосування права вето як новими, так і чинними членами;

- ненаділення нових постійних членів РБ ООН правом вето;

- нові постійні члени РБ ООН повинні висловити готовність отримати цей статус без отримання права вето або ж бути згодними застосовувати право вето до завершення процедури періодичної оцінки розширеної Ради тощо [11].

Водночас висловлювалися пропозиції збереження право вето в поточній формі [11].

У результаті проведеного аналізу вищенаведених пропозицій можна дійти висновку, що Робоча група, яка їх формулювала, опинилися одразу між «кількох вогнів»: очевидним бажанням потенційних нових постійних членів РБ ООН володіти всіма елементами їхнього поточного міжнародно-правового статусу, зокрема правом вето; неготовністю чинних постійних членів ділити своє чи не ключове повноваження з іншими державами; ініціативами щодо обмеження чи скасування права вето у принципі тощо.

Особливо активно в цьому контексті обговорювалося питання про обмеження чи скасування права вето постійних членів РБ ООН. Зокрема, у пропозиціях, які були включені до звіту, підкреслювалося: «Постійні члени Ради повинні вживати «обмежень у застосуванні права вето», а також висловлювалися ідеї, що право вето повинно застосовуватися лише із «життєво важливих питань» для ООН. Також пропонувався протилежний підхід - заборонити застосування права вето щодо питань відповідно до розд. VII Статуту ООН [11].

Більш однозначно щодо можливості надання права вето новим постійним членам РБ ООН висловилася Спеціальна комісія міжнародних експертів у своїй доповіді 2004 р. У ній чітко зафіксована пропозиція, що «за будь-якого проєкту реформування не повинно мати місце розширення права вето» [3].

Тобто міжнародні експерти прагнули, по суті, увести мораторій на застосування цього інструменту, але не в цілях монополізації цього права постійними членами РБ ООН, а через його, як уважали експерти, анахронічний характер. Крім того, експерти висловлювали пропозиції щодо обмеження права вето, зокрема, закликали обмежити його застосування лише тими питаннями, «у яких справді поставлені на карту життєво важливі інтереси» [3].

Крім пропозицій щодо скасування права вето або ж мораторію на його поширення на нових постійних членів РБ ООН, висловлюють й інші. Наприклад, Спе- 
ціальна комісія міжнародних експертів у своїй доповіді 2004 р. пропонувала ввести практику так званого індикативного (сигнального) голосування, яке давало б змогу попередньо зафіксувати позицію всіх членів РБ ООН із певного питання і не призводило б до ухвалення юридично обов'язкових рішень. На думку експертів, це давало б змогу «підвищити відповідальність за застосування права вето» [3].

Підсумовуючи, варто зазначити, щоскасування права ветопостійних членів Ради Безпеки ООН є одним із найбільш дискутованих питань щодо реформування внутрішньорганізаційного механізму ООН у доктрині права міжнародних організацій. Як у науці, так і у практиці, за підсумками міжнародного права діяльності спеціальних тимчасових органів ООН напрацьована низка пропозицій щодо цього, зокрема його цілковите скасування, обмеження або ж зміну порядку його застосування.

Водночас будь-які зміни міжнародно правового статусу постійних членів Ради Безпеки ООН можливі відповідно із процедурою, передбаченою Статутом ОOH. Також, на нашу думку, пошук шляхів вирішення цієї проблеми є невіддільним від розв’язання інших аспектів міжнародно-правового статусу постійних членів Радбезу, зокрема їх кількісного складу.

\section{Jimepamypa}

1. The Charter of the United Nations : A Commentary / Edts. B. Simma et al. 3rd Edt. Oxford : Oxford University Press, 2002. $1236 \mathrm{p}$.

2. Губань Р. Проблеми реалізації проектів реформи Ради Безпеки ООН. Юридичний журнал. 2007. № 11. C. $64-73$.

3. A More Secure World: Our Shared Responsibility Report of the Secretary-General's High-level Panel on Threats, Challenges and Change: A/59/565 of 2 December 2004. United Nations General Assembly. Cit. 08.10.2020. URL : https://documents-dds-ny.un.org/doc/UNDOC/GEN/N04/602/31/PDF/ N0460231.pdf?OpenElement.

4. Wilcox F.O. II. The Yalta Voting Formula. American Political Science Review. 1945. Vol. 39. P. 943-956.

5. Устав Организации Объединенных Наций и Устав Международного Суда от 26 июня 1945 г. Цит. 18.09.2019 г. URL: http://zakon2.rada.gov.ua/laws/show/995_010.

6. Competence of Assembly regarding admission to the United Nations, Advisory Opinion : I.C. J. Refiorts $1950,57 \mathrm{p}$.

7. Черінько І. Проблеми реформування Ради Безпеки ООН. Актуальні проблеми міжнародних відносин. 2011. Вип. 96. Ч. І. С. 138-139.

8. Дорош Л., Охремчук С. РБ ООН у сучасних умовах: до проблеми пошуку варіантів реформування. Humanitarian vision. 2015. Vol. 1. № 2. С. 19-26.

9. Маланчук П. Вступ до міжнародного права за Ейкхерстом. Пер. з англ. 7-е вид., переробл. Харків : Консум, 2000. $591 \mathrm{c.}$

10. The Security Council and the Use of Force: Theory and Reality. A Need for Change? / N. Blokker, N. Schrijver. Leiden : Brill Nijhoff, 2005. 312 p.

11. Report of the Open-ended Working Group on the Question of Equitable Representation on and Increase in the Membership of the Security Council and Other Matters related to the Security Council : Supplement № 47 (A/55/47) / UN General Assembly. New York : United Nations, 2001. 177 p. 


\section{Анотація}

Хостюк I. В. Міжнародно-правова проблематика скасування права вето постійних членів Ради Безпеки Організації Об’єднаних Націй. - Стаття.

Постійні члени Ради Безпеки Організації Об’єднаних Націй є важливим елементом міжнародно-правової системи миру та безпеки, яка постала після Другої світової війни. Водночас право вето $€$ одним із ключових елементів їхнього міжнародно-правового статусу. Первинно воно постало як гарантія стабільної діяльності Радбезу та забезпечення балансу між великими державами в умовах холодної війни. Проте в багатьох випадках цей юридичний інструмент став інструментом політичної помсти в умовах біполярного світу.

Така ситуація призвела до значної критики самого факту існування та застосування цього інструменту як своєрідного «гальма» для ефективної діяльності Організації Об'єднаних Націй загалом. Тому скасування права вето є одним із найбільш обговорюваних питань міжнародно-правового дискурсу навколо реформування Ради Безпеки Організації Об'єднаних Націй, правових основ статусу постійних членів Ради.

У статті розглядаються міжнародно-правові пропозиції щодо скасування або реформування права вето постійних членів Ради Безпеки Організації Об’єднаних Націй. Особлива увага приділяється напрацюванню офіційних міжнародних робочих груп у рамках Організації Об'єднаних Націй. Виділяються юридичні основні пропозиції стосовно реформування права вето.

Робиться висновок, що питання реформування повноважень постійних членів Ради Безпеки Організації Об'єднаних Націй щодо застосування права вето ще тривалий час залишатиметься однією 3 найбільш актуальних проблем сучасного міжнародного публічного права в контексті реформування Організації Об'єднаних Націй загалом. Чинні пропозиції, напрацьовані як в науці права міжнародних організацій, так і у практичній діяльності Організації Об’єднаних Націй, передбачають три основні шляхи проведення змін: цілковите скасування права вето, обмеження або зміну порядку його застосування.

Підкреслюється, що Статут Організації Об’єднаних Націй передбачає спеціальну процедуру щодо внесення змін до нього, реформування чи скасування права вето має бути здійснене відповідно до цієї процедури. Особливий акцент робиться на взаємопов'язаності міжнародно-правового дискурсу щодо скасування права вето постійних членів Ради Безпеки Організації Об'єднаних Націй та інших питань їхнього правового статусу, зокрема і скорочення чи збільшення їхнього кількісного складу.

Ключові слова: право вето, реформування ООН, Рада Безпеки ООН.

\section{Summary}

Khostyuk I. V. International legal issues of abolishing the "power of veto" of permanent members of the UN Security Council. - Article.

The permanent members of the UN Security Council are an important element of the international legal system that emerged after the Second World War. At the same time, the power of veto is one of the key elements of their international legal status. Initially, it emerged as a guarantee of stable activity of the Security Council and ensuring a balance between the great powers in the Cold War. However, in many cases, this legal instrument has become a tool for settling political accounts in a bipolar world.

This situation has led to significant criticism of the very existence and use of this tool as a kind of "brake" for the effective functioning of the United Nations as a whole. Therefore, the abolition of the power of veto is one of the most discussed issues of international legal discourse around the reform of the UN Security Council and, in fact, the legal basis for the status of permanent members of the Council.

The article considers international legal proposals to abolish or reform the power of veto of permanent members of the UN Security Council. Particular attention is paid to the work of official international working groups within the UN. The main legal proposals for reforming the right of veto are highlighted.

It is concluded that the abolition of the power of veto of permanent members of the UN Security Council is one of the most discussed issues related to the reform of the UN internal mechanism in the doctrine of the law of international organizations. Both in doctrine and in practice, following the results of the international law of activity of special temporary bodies of the UN, a number of offers in this occasion, in particular, its full cancellation, restriction or change of the order of its application is developed.

Key words: power of veto, UN reform, UN Security Council. 